\title{
PENERAPAN STRATEGI REDIFINISI KONSTEKSTUAL UNTUK MENINGKATKAN PENGUASAAN KOSAKATA DAN AKTIVITAS PEMBELAJARAN
}

\author{
St. Nurbaya \\ Fakultas Bahasa dan Seni Universitas Negeri Yogyakarta \\ email: st_nurbaya@yahoo.co.id
}

\begin{abstract}
This study aims to improve learning activities and vocabulary mastery by applying a contextual learning strategy of redefinition in Indonesian. This was an action research study involving the students of Class VIII E of SMP Negeri I Seyegan, Sleman, Yogyakarta. The data were collected through observations, interviews, documents, and a vocabulary test. The research instruments included an interview guide, a checklist, and observation guide, and a vocabulary test. The data were qualitatively described. The results showed that the contextual redefinition strategy managed to improve the vocabulary mastery and learning activities. The students' vocabulary mastery improved after each action cycle. The learning activities included raising questions, examining the correspondence between questions and learning materials, using dictionaries to verify word meanings, having discussions, and constructing sentences to express contextual meanings.
\end{abstract}

Keywords: contextual redefinition strategy, vocabulary mastery, learning activities

\section{PENDAHULUAN}

Penguasaan kosakata dapat mempengaruhi kemampuan berbahasa yang lain seperti membaca, sehingga kemampuan memahami makna kata menjadi prasyarat untuk menguasai aspek keterampilan berbahasa yang lain. Penguasaan kosakata dalam suatu bahasa oleh seseorang juga menjadi kunci untuk memahami berbagai informasi yang tertuang dalam bahasa tulis maupun dalam bahasa lisan. Hal ini menunjukkan, bahwa penguasaan kosakata dan kemampuan memahami informasi memiliki hubungan timbal balik yang saling mempengaruhi. Hubungan timbal balik antara kosakata dengan aspek keterampilan membaca misalnya, tergambar pada upaya metakognisi pembaca untuk melakukan penyandian kembali kata-kata yang digunakan oleh penulis dalam teks yang dibaca secara cepat, te- pat, dan memaknainya serta menginterpretasikan kembali secara bersamaan untuk memperoleh makna yang komprehensif dari teks yang dibaca.

Pembelajaran kosakata yang dilakukan oleh guru, dilakukan dengan strategi ceramah. Proses pembelajaran yang dilakukan dengan srategi ceramah memposisikan guru sebagai kamus berjalan dan sesekali menggunakan kamus untuk memaknai kosakata sulit yang dihadapi. Keadaan ini terjadi karena guru belum mengenal berbagai strategi inovasi pembelajaran. Guru masih menggunakan strategi pembelajaran buka kamus, ceramah atau dengan perkataan lain implementasi strategi pembelajaran kosakata guru belumlah bervariasi. Hal ini tergambar dengan jelas dari pengakuan guru bahasa Indonesia ketika beberapa kali peneliti melakukan wawancara dan mengamati proses pembelajaran yang 
dilakukan oleh guru bahasa Indonesia (Ibu Endang Nurhidayati pada tanggal 3 April 2006, dan tanggal 6 April 2006).

Pembelajaran kosakata dengan strategi tradisional seperti di atas menjadi tidak menarik, dan yang "menyedihkan" pembelajaran dengan strategi tradisional tidak menjadikan siswa lebih kooperatif, siswa apatis, dan bosan sehingga tidak berpengaruh banyak terhadap peningkatan pengusaan kosakata siswa. Hasil penyebaran angket prapenelitian atau pratindakan pada tanggal (1 April, 2006) menunjukkan bahwa $77 \%$ siswa tidak berminat terhadap pembelajaran pemahaman isi bacaan, dan kosakata yang dilakukan hanya dengan strategi buka kamus dan strategi ceramah.

Tierney (1999:196) menawarkan beberapa strategi pembelajaran kosakata yang dapat dijadikan alternatif pembelajaran selain strategi buka kamus, ceramah dan tanya jawab. Strategi yang dimaksud adalah, Possible Sentences. List-Group-Label, Contekstual Redefinition, Previeu in Context, Feature Analysis, Word Map, Vocabulery Self-Collection, dan Key-Method. Hasil diskusi kolaborator dengan guru menyepakati bahwa untuk kosakata dan rendahnya aktivitas pembelajaran adalah mencoba mengimplementasikan strategi Contextual Redefinition dalam pembelajaran.

Para ahli mendefinisikan kosakata berbeda-beda. Dalam jurnal Brainy Auote yang di muat dalam www. brainyquote.com/words/vo/vocabulary, kosakata dimaknai sebagai a list or collection of words arranged in alphabetical order and explained; a dictionary or lexicon, either of a whole language, a single work or author, a branch of science, or the like, a word-book. Sementara Diamond \& Gutlohn (2006:1) mengatakan bahwa kosakata adalah pemahaman seseorang tentang sejumlah kosakata beserta maknanya, hal ini terungkap dalam situs www.readingrock- ets. org/article yang menyatakan bahwa: vocabulary is the knowledge of words and word meanings. Pengertian yang diungkapkan oleh Diamond \& Gutlohn lebih sederhana karena keduanya tidak mempersoalkan apakah kosakata tersebut digunakan atau tidak oleh seseorang ketika berkomunikasi.

Berbeda dengan dua pengertian di atas kosakata juga mengandung pengertian sebagai (1) all the words of a language (2) the sum of words used by, understood by, or at the command of a particular person or group (3) a list of words and often phrases, usually arranged alphabetically and defined or translated; a lexicon or glossary (4) a supply of expressive means; a repertoire of communication (www.thefreedictionary.com/ vocabulary)

Uraian Mifflin tentang kosakata bersifat multi definisi yang terkait dengan hal-hal, yaitu (a) semua kata dalam suatu bahasa, (b) sejumlah kata yang digunakan, dipahami pada perintah dari seseorang atau kelompok, (c) daftar kata atau frase, biasanya diatur secara berurutan menurut abjad dan didefinisikan atau diterjemahkan, dan (d) alat untuk mengekpresikan lakon.

Pemerian kosakata yang lebih spesifik dapat dilihat pada apa yang dikatakan oleh Collins (2006:1) dalam www.thefreedictionary.com/vocabulary. Collins mendefinisikan kosakata lebih rinci yakni: "(1) all the words that a person knows (2) all the words contained in a language (3) the specialist terms used in a given subject (4) a list of words in another language with their translations (5) a range of symbols or techniques as used in any of the arts or crafts".

Selanjutnya, strategi Contextual Redefinition adalah salah satu strategi pembelajaran kosakata yang ditawarkan Tierney. Sebagai sebuah strategi pembelajaran, strategi Contextual Redefinition dapat dijadikan alternatif pembelajaran kosakata, yang tujuannya dirancang 
khusus untuk membantu siswa dalam (a) menggunakan konteks untuk menemukan makna kata kata sulit, (b) membuat perkiraan yang relevan tentang makna kata sesuai dengan konteks sehingga terhindar dari perkiraan makna secara serampangan.

Sesuai dengan namanya yang menekankan pada adanya prediksi makna kata, dan memverifikasi kata berdasarkan konteks maka upaya menemukan makna kata dengan strategi Contextual Redefinition menempatkan siswa sebagai objek pembelajaran yang harus senantiasa berproses, dalam arti senantiasa menggunakan nalarnya untuk mencoba-coba menemukan makna kata yang akan ditemukan. Karena siswa senantiasa akan menggunakan nalarnya, maka siswa bebas "berkreasi", "membuat", "menemukan", "memperkiraan" makna kata yang ada dalam teks dan memantau makna kata tersebut dengan memeriksa ketepatan sintaksis dan simantik sesuai perkembangan bacaan.

\section{METODE}

Penelitian ini menggunakan metode penelitian Tindakan Kelas dengan mengimplementasikan model yang ditawarkan oleh Kemmis dan Mc. Taggart. Subjek penelitian 36 siswa kelas VIII SMP Negeri 1 Seyegan Sleman. Teknik analisis data dilakukan secara kuantitatf dan kualitatif. Adapun strategi yang diimplementasikan adalah stratgei Contextual Redefinition dengan langkahlangkah sebagai berikut.

Pertama, kata-kata yang akan dicari makna dengan strategi ini adalah kata-kata yang diidentifikasi dalam hubungannya dengan bahan bacaan yang ada, jadi bukan kata-kata yang yang dipilih secara acak. Sebelum menggunakan strategi ini dalam pembelajaran, para guru harus membaca dan memeriksa bacaan, sehingga menemukan (a) kata-kata penting dalam teks yang harus dipahami siswa, (b) katakata yang mungkin sulit dipahami oleh siswa ketika membaca teks bacaan.

Kedua, guru menyediakan sekurang-kurangnya satu kalimat, agar siswa mempunyai petunjuk yang tepat untuk menemukan makna kata, dan apabila kalimat telah mempunyai konterks yang tepat, maka kalimat tersebut dapat digunakan, dan jika tidak ada konteks, guru membuat sebuah kalimat konteks yang dapat dijadikan sebagai petunjuk oleh siswa untuk menemukan makna kata. Jika kalimat telah disediakan, maka guru dapat menggunakan berbagai macam petunjuk seperti sinonim, perbandingan, definisi, dan lainlain. Dengan bantuan cara seperti yang dijelaskan seperti di atas, maka siswa dapat menemukan makna kata.

Ketiga, menempatkan kata secara sendiri-sendiri, dengan menggunakan papan tulis atau alat pembelajaran lainnya, guru meminta siswa untuk membuat definisi masing-masing kata tersebut. Pada saat memberikan perkiraan makna kata, siswa harus memiliki argumentasi yang dapat dijadikan dasar mengapa makna itu yang dimaksud. Cara ini dapat dilakukan dengan berkelompok, dengan berdiskusi siswa akan menemukan makna kata yang relevan. Dalam proses ini mungkin akan ada beberapa makna kata yang dikemukakan oleh siswa yang tidak relevan, tetapi ini merupakan sebuah proses belajar yang harus dihargai.

Keempat, meletakkan kata dalam konteks.Tahap ini siswa dihadapkan pada kalimat yang bersisi kata-kata yang akan dicari makna dalam konteks tertentu. Para siswa diminta untuk memberikan prediksi tentang makna kata tertentu dan menyediakan sebuah alasan untuk memberikan definisi. Pada tahap ini siswa telah menjalani proses berpikir dalam menemukan makna kata, atau siswa telah mampu bertin- 
dak sebagai model dari sikap membaca yang tepat diantara satu dengan yang lainnya. Meskipun demikian siswa secara individu harus turut mencari atau memprediksi makna kata yang ada. Pada tahap ini juga siswa harus mengetahui bahwa konteks membutuhkan banyak informasi menganai makna kata dan memperkirakan mana makna yang paling relevan.

Kelima, menggunakan kamus untuk verifikasi. Tahap ini melatih siswa untuk membuka dan mencari makna kata sesuai dengan kamus, hal ini dilakukan untuk mencocokan makna kata yang telah diverifikasi. Tahap ini dilakukan pada sesi akhir pelajaran. Tahap ini juga menjadi ajang untuk mendiskusikan perkiraan makna kata ketika kata tersebut dimasukkan dalam (a) tempat khusus, (b) dalam konteks. Peran guru pada tahap ini hanya menjadi fasilitator, pada saat siswa berusaha menemukan perbedaan makna kata ketika mendefinisikan kembali secara kontekstual.

\section{HASIL DAN PEMBAHASAN}

Penelitian ini dilaksanakan dalam tiga siklus dengan rancangan pembelajaran yang menekankan pada implementasi strategi Contextual Redefinition. Proses pemerolehan data dan proses evaluasi dilakukan dengan mengamati dan mencatat semua aktivitas dan kegiatan pembelajaran yang dilakukan siswa, serta memperhatikan skor kosakata yang diperoleh siswa. Pembahasan hasil penilitian dalam tiap siklus diuraikan seperti berikut ini.

\section{Penguasaan Kosakata}

Rerata skor penguasaan kosakata siswa pada awal penelitian atau pada saat pratindakan adalah $(26,30)$ dan skor rerata penguasaan kosakata pada akhir tindakan siklus pertama adalah $(28,00)$, hal ini menunjukkan bahwa pada siklus pertama tindakan terjadi peningkatan penguasaan skor penguasaan kosakata $(1,7)$. Peningkatan penguasaan kosakata siswa ketika peneliian ini berlangsung mencerminkan adanya kemampuan kognisi dan intelegensi siswa yang dapat dioptimalkan fungsinya oleh guru ketika pembelajarn berlangsung.

Rerata skor penguasaan kosakata pada siklus pertama adalah $(28,00)$ dan rerata skor penguasaan kosakata siklus kedua adalah $(32,77)$. Selisih rerata skor penguasan kosakata siklus pertama ke rerata skor akhir penguasaan kosakata siklus kedua adalah $(4,77)$ menunjukkan bahwa ada peningkatan penguasaan kosata siswa pada siklus pertama dibandingkan dengan siklus kedua.

Berdasarkan data hasil penelitian yang diungkapkan di atas dapat disimpulkan bahwa stratgei Contextual Redefinition dapat meningkatkan penguasaan kosakata siswa. Pada siklus kedua terlihat juga peningkatan aktivitas belajar siswa, terutama aktivitas mencari makna kata dalam konteks dengan menggunakan kalimat yang dibuat sendiri oleh siswa. Arahan utama dalam siklus ini adalah memperbanyak membuat kalimat dengan menggunakan kosakata yang akan dicari maknanya menjadikan siswa dapat memperoleh berbagai makna pemahaman bacaan, seperti misalnya makna kata "semburat".

Berdasarkan perhitungan rerata penguasaan kosakata siswa pada siklus kedua adalah (32.77) dan rerata skor siklus ketiga adalah (36.27). Dengan demikian terdapat selisih tingkat penguasaan kosakata siswa antara siklus kedua dan siklus ketiga sebesar (4.00). Peningkatan ini menujukkan peningkatan yang signifikan. Peningkatan yang signifikan dari setiap siklus penelitian yang dilakukan mengindikasikan bahwa sebuah hasil refleksi yang dilakukan secara cermat dan penentuan tindakan perbaikan dalam setiap siklus menun- 
jukkan adanya nilai keefektifan sebuah desain pembelajaran.

Secara keseluruhan dalam 3 siklus penguasaan kosakata yang mengalami kenaikan yang mencapai $(9,42)$ menunjukkan adanya efektifitas pembelajaran yang tinggi. Hal ini bukan tanpa alasan, kemampuan dan ketepatan mengambil keputusan dalam upaya memperbaiki setiap detail kekurangan yang teramati pada setiap siklus menunjukkan suatu pengambilan keputusan yang dilakukan secara sadar yang berkelanjutan yang membuahkan hasil. Pemberian tes atau latihan maupun tugas-tugas yang direncanakan secara matang pada setiap akhir siklus juga menujukkan proses pemblajaran yang yang terarah dan terkontrol, hal ini sejalan dengan uraian Stinggins (1994) seperti dikutip dari Yusraffindin dan Sunu Dwi Antoro (2010:347) tentang tujuh prinsip penilaian proses seperti berikut .

Pertama, penilaian proses merupakan suatu penilaian yang memerlukan pemikiran yang jernih dan komunikatif, kedua sebagain besar dari proses pembelajaran yang diselenggarakan mengandung penilaian, ketiga guru harus menyadari sepenuhnya bahwa siswalah yang paling membutuhkan penilain proses, keempat kualitas penilain proses sangat ditentukan oleh kejelasan target belajar yang akan dinilai, kelima kualitas penilaian merupakan tuntutan terhadap semua penilain proses, keenam penilaian merupakan hubungan antar personal yang sangat kompleks, ketujuh penilaian memiliki hubungan dengan pembelajaran sehingga antara penilaian dan pembelajaran memiliki satu kesatuan yang menempatkan penilaian sebagai alat pembelajaran yang baik, dan materi pembelajaran merupakan bahan penilaian.

Berdasarkan ketujuh aspek penilaian proses di atas maka penilain proses yang digunakan oleh guru tidak semata-mata sebagai suatu kegitan menilai siswa dalam bentuk pemberian nilai berupa angka-angka yang mengarah pada penilaian prestasi belajar, tetapi merupakan sebuah proses pembelajaran yang mencakup semua komponen baik sikap, prilaku, motivasi, perhatian yang teramati pada saat pembelajaran berlangsung.

\section{Aktivitas Pembelajaran \\ Keaktifan Siswa Mengikuti Langkah Mencari dan Menemukan Makna Kata}

Instrumen yang digunakan untuk mengamati keaktifan siswa dalam mengikuti pembelajaran adalah daftar ceklist dengan enam aspek. Aspek pertama yang diamati dalam pembelajaran adalah keaktifan siswa mengikuti langkah-langkah strategi Contextual Redefinition ketika pembelajaran berlangsung memperlihatkan bahwa 7 orang siswa sangat aktif mengikuti langkah demi langkah pencarian makna kata dengan strategi Contextual Redefinition atau sebanyak 19,44\%, 9 orang aktif atau 25\%, dan 14 orang atau 38,88\% tidak aktif mengikuti langkah-langkah strategi pembelajaran.

Secara keseluruhan amatan pada siklus pertama ini memperlihatkan bahwa kondisi kelas masih sama dengan kondisi pratindakan, hasil diskusi dengan guru kolaborator menyatakan bahwa siswa yang 7 orang atau yang 19,44\% tersebut adalah siswa yang dalam pembelajaran sehari-hari memiliki motivasi belajar yang lebih baik dengan temantemannya yang lain, demikian halnya dengan yang 9 orang atau yang 25\% merupakan siswa yang prestasi atau motivasi belajarnya sedang, sedangkan yang 14 orang atau yang 38,88 \% merupakan anak-anak yang motivasi belajarnya rendah. Data ini menunjukkan bahwa pada siklus pertama aktivitas pembelajaran belum berjalan maksimal atau dengan kata lain yang aktif 
belajar atau yang memberikan respon terhadap proses pembelajaran dengan strategi Contextual Redefinition adalah siswa-siswa yang pada dasarnya memiliki motivasi belajar yang lebih baik secara individu dari teman-temannya yang lain. Oleh sebab itu seorang guru yang menerapkan strategi tertentu ketika pembelajaran berlangsung harus faham betul terhadap pengaruh faktorfaktor psikologis dalam keberhasilan pembelajaran bahasa (Brown, 2004 : 121). Selain itu guru juga harus mampu membangkitkan keinginan siswa untuk membagun komunikasi dan menghargai dan menghormati masing-masing individu

\section{Keaktifan Bertanya}

Hasil amatan terkait keaktifan bertanya memperlihatkan bahwa hanya 5 orang siswa yang sering sekali bertanya atau sering sekali mengajukan pertanyaan atau hanya $16.66 \%$, dan yang sering mengajukan pertanyaan sebanyak 12 anak atau 33,33\% sisanya yang tidak pernah mengajukan pertanyaan sebanyak 50,00\%. Kondisi ini juga menunjukkan kalau siswa masih apatis dan tidak responsif ketika pembelajaran berlangsung. Katika diminta untuk memberikan komentar atau pertanyaan kebanyak dianatara mereka atau 50,00\% tidak bertanya, hal dipsebabkan kondisi alamiah siswa yang tidak terbiasa bertanya atau mungkin tidak terbiasa dengan suasana pembelajaran yang interaktif. Kondisi seperti ini dalam pembelajaran tidak dapat dibiarkan, guru harus mampu membangkitkan rasa ingin tahu siswa.

Pembiasaan yang dipaksakan secara terus-menerus dapat membantu menumbuhkan keberanian siswa untuk bertanya, selain itu situasi pembelajaran yang demokrtispun harus ditumbuhkan dengan cara setiap siswa diminta untuk menjadi pendengar yang baik sebelum memberiakn komentar terhadap apa yang ditanyatakan atau dibicarakan oleh siswa lainnya. Pemerataan kesempatan bertanya dan menjawab harus dijelaskan pada awal pembelajaran berlangsung, sehingga tipa siswa memiliki tugas, hak, dan kewajiban yang harus dilaksanakan selama pembelajaran berlangsung.

Hasil diskusi dan refleksi dengan guru kolaborator, keenam siswa yang mengajukan pertanyaan pada siklus ini, menujukkan siswa yang dalam pembelajaran sehari-hari juga merupakan siswa yang aktif, sehingga dapat dikatakan bahwa pada siklus pertama untuk keaktivan siswa belum ada perubahan atau belum ada peningkatan dari pratindakan. Kondisi ini harus diperbaiki pada siklus kedua.

\section{Kesesuaian Pertanyaan dengan Materi Pembelajaran}

Pada aspek keaktifan bertanya di atas, aspek yang diamati terkait dengan inisiatif siswa untuk mengajukan pertanyaan pada saat pembelajaran berlangsung, sedangkan pada aspek kesesuaian pertanyan dengan materi pembelajaran adalah amatan yang dilakukan ketika guru mengajukan pertanyaan dan kesesuaian jawaban yang diberikan oleh siswa saat menjawab

Dari hasil amatan ada 10 orang atau $13,88 \%$ siswa yang menjawab pertanyaan guru dengan benar terkait dengan makna kata, baik makna dalam konteks maupun maknal lepas (kata yang ditanyakan adalah merona, medical), ada 16 anak atau 44,44\% siswa yang menjawab pertanyaan yang menekati kebenaran, dan 15 atau 41,66 \% siswa menjawab tidak dengan benar pertanyaan yang diajukan oleh guru. Data ini menunjukkan bahwa antara siswa yang menjawab pertanyaan dengan benar masih sedikit jika dibandingkan dengan siswa yang menjawab dengan tidak atau 
belum benar, akan tetapi meskipun demikian indikasi dari keterlibatan siswa dalam pembelajaran, khususnya pada aspek keaktivan bertanya mulai membaik, meski baru sampai pada tahap memberikan jawaban yang mendekati kebenaran. Hal ini mengindikasikan bahwa siswa mulai terlibat aktif dalam pembelajaran meski baru pada taraf mengemukakan pendapat berkaitan dengan pertanyaan guru tentang makna kata yang ditanyakan.

\section{Keaktifan Berdiskusi dengan Teman Sekelompok}

Untuk mendapatkan makna kata secara lepas dalam salah satu langkah yang ada dalam strategi Contextual Redefinition adalah menggunakan kamus. Pamanfaatan kamus adalah untuk memferifikasi makna kata yang ditemukan. Pada aspek ini ada 6 orang siswa atau $16,66 \%$ yang sering sekali menggunakan kamus untuk verifikasi, 9 orang hanya beberapa kali menggunakan atau 25\% dan 14 orang atau 38,88\% yang tidak menggunakan kamus untuk memferifikasi makna kata. Kondisi ini disebabkan kurangnya kamus yang disediakan, kamus yang disediakan hanya 2, sementara kelompoknya ada 6. (e) Keaktifan berdiskusi dengan teman sekelompok

Berdiskusi dengan teman sekelompok merupakan langkah yang ada dalam strategi Contextual Redefinition, langkah ini merupakan suatu upaya untuk menemukan makna kata baik makna lepas maupun makna konteks. Langkah ini sangat menentukan penguasaan makna kata, karena pada langkah ini siswa akan menemukan berbagi ragam makna kata hasil diskusi antara siswa dengan siswa. Dari hasil amatan terdapat 8 orang siswa atau sebanyak $22,22 \%$ siswa yang sangat intens berdiskusi dengan temannya untuk mencari dan menemukan makna kata, 13 orang atau $36,11 \%$ siswa yang berdiskusi un- tuk menemukan makna kata, dan ada 14 atau 38,88\% orang yang tidak sama sekali berdiskusi untuk menemukan makna kata sesuai dengan langkah stratgei Contexstual Redefinition.

\section{Keaktifan Menyusun Kalimat untuk Menentukan Makna Konteks}

Langkah menyusunan kalimat dari beberapa contoh kalimat yang ada dalam stratgei Contextual Redefinition merupakan langkah utama yang akan menjadi kunci siswa menemukan makna kata yang dicari. Dari langkah ini siswa akan berkreasi membuat kalimat untuk dapat membedakan berbagai makna kata yang dicari. Meskipun pada langkah sebelumnya berupa diskusi mencari makna kata siswa juga akan menemukan makna kata, tetapi pada langkah, menyusun kalimat dilakukan oleh siswa dengan membuat kalimat sendiri atau menggunakan kalimat yang telah disiapkan oleh guru. Siswa yang sangat aktif menulis kalimat untuk mencaricari berbagai makna kata ada 9 orang atau sebayak 25,00\%, sedangkan yang hanya sesekali membuat kalimat atau menggunakan kalimat sendiri untuk mencari makna kata sebanyak 11 orang atau $30,55 \%$ dan yang tidak sama sekali membuat kalimat ada 16 orang atau sebanyak $44,44 \%$.

Hal diatas ini menunjukkan bahwa upaya implementasi strategi Contextual Redefinition belum memenuhi target yang diinginkan. Oleh sebab itu peneliti dan kolaborator menyepakati pada siklus kedua perlu merangsang dan memotivasi siswa untuk terlibat secara aktif dalam pembelajaran. Upaya yang dilakukan adalah dengan memberikan pertanyaan yang terfokus pada siswa yang belum aktif, atau mengharuskan siswa bertanya pada siswa yang tidak aktif.

Pembelajaran siklus kedua dilakukan pada hari Senin dan Rabu 
tanggal 18 dan 21 April 2006. Seperti disepakati pada siklus pertama di atas, bahwa pada siklus kedua ini pengamatan proses difokuskan pada upaya peningkatan aktivitas siswa dalam enam aspek yang diamati. Tiap siswa yang belum aktif pada siklus pertama mendapat perhatian khusus pada siklus kedua.

Keaktifan siswa siklus kedua ini mengalami peningkatan dalam semua aspek yang diamati. Empat belas siswa atau 38,88\% sangat aktif mengikuti semua langkah mencari dan menemukan makna kata, atau ada peningkatan 14,44\% dari siklus pertama. Ada 12 orang atau $33,33 \%$ siswa teramati aktif mengikuti semua langkah strategi Contextual Redefinition dalam menemukan makna kata, hal ini menunjukkan ada peningkatan 1,33\% dari siklus pertama, dan ada 8 orang atau 22,22\% yang tidak seluruhnya mengikuti langkah-langkah mencari makna kata dalam strategi Contextual Redefinition ada selisih $16.66 \%$ dari siklus pertama, sehingga dapat dikatakan memiliki peningkatan. Peningkatan aktivitas belajar siswa menunjukkan keberhasilan sebuah upaya. Selain itu peningkatan ini juga menunjukkan bahwa untuk meningkatkan motivasi dan keaktifan siswa sangat dipengaruhi oleh kemampuan guru mengelola pembelajaran.

Pada siklus pertama siswa yang aktif bertanya hanya 5 orang atau seki$\operatorname{tar} 16.66 \%$, pada siklus kedua keaktifan siswa yang sangat aktif bertanya mengalami peningkatan menjadi 13 orang atau $36,11 \%$, terdapat peningkatan $19,45 \%$ dari siklus pertama, sedangkan siswa yang cukup aktif mengajukan pertanyaan menjadi 10 orang atau $27,775 \%$ dan menujukkan ada peningkatan sebesar $11.11 \%$ sedangkan yang tidak aktif atau tidak mengajukan pertanyaan sama sekali ada 6 orang atau 16,66\% dan jika dibandingkan dengan aktifitas pada siklus pertama terjadi peningkatan sebe sar $22.23 \%$. Peningkatan aktifitas mengajukan pertanyaan yang paling tinggi pada siklus ini terjadi pada siswa yang pada awalnya tidak mengajukan pertanyaan sama sekali, hal ini terjadi dimungkin-kan karena tiap siswa yang belum sama sekali mengajukan pertanyaan diminta untuk mengajukan pertanyaan, dan usaha ini membuahkan hasil, sehingga situasi pembelajaran menjadi lebih dinamis.

Siklus kedua pembelajaran terjadi penurunan pertanyaan yang relevan dengan materi pertanyaan. Jika pada siklus pertama ada 10 orang atau 13,88\% siswa yang pertanyaanya sangat sesuai dengan materi pembelajaran, maka pada siklus kedua hanya 9 orang atau hanya $22,77 \%$. Akan tetapi siswa yang mengajukan pertanyaan yang sesuai dengan materi tetap sama yakni 16 orang atau $44,44 \%$, dan ada 11 orang siswa atau $30,50 \%$ yang mengajukan pertanyaan tidak berkaitan dengan konteks pembelajaran atau tidak relevan dengan materi pembelajaran.

Untuk mendapatkan makna kata secara lepas dalam salah satu langkah yang ada dalam strategi Contextual Redefinition adalah menggunakan kamus untuk memverifikasi makna kata yang ditemukan. Pada aspek penggunaan kamus untuk mencari makna kata terjadi peningkatan jumlah siswa yang sangat sering menggunakan kamus yakni dari 9 orang menjai 11 orang atau 30,55\% sehingga ada selisih kenaikan sebanyak $13,89 \%$, siswa yang sering menggunakan kamus untuk verifikasi makna kata 17 orang atau sebanyak 47,22\% atau mengalami peningkatan sebanyak $22,22 \%$, dan masih ada 12 orang yang belum aktif menggunakan kamus atau $33,33 \%$, tetapi jika dibandingkan dengan siklus pertama, pada siklus kedua ini jumlah anak yang belum menggunakan kamus untuk memverifikasi makna kata terjadi peningkatan yang semula 
ada 14 anak atau 38,88\% menjadi 12 anak atau $33,33 \%$, dan selisih peningkatan ada $5,55 \%$.

Langkah berdiskusi dengan teman sekelompok merupakan langkah untuk menemukan makna kata baik makna lepas maupun makna konteks. Langkah ini sangat menentukan penguasaan makna kata, karena pada langkah ini siswa akan menemukan berbagai ragam makna kata hasil diskusi antara siswa dengan siswa. Siklus kedua penelitian menujukkan ada peningkatan siswa yang terlibat dalam diskusi, jika pada siklus pertama hasil amatan terdapat 8 orang siswa atau sebanyak $22,22 \%$ siswa yang berdiskusi sangat intens dengan temannya untuk mencari dan menemukan makna kata, maka pada siklus kedua terjadi kenaikan siswa yang terlibat diskusi yang intens dengan temannya yakni 11 orang atau $30,55 \%$ atau ada kenaikan sebesar 8,33\% sedangkan siswa yang masih belum aktif berdiskusi dengan temannya menurun menjadi 9 orang atau masih 25\%, atau ada kenaikan sebanyak $11,11 \%$ dan yang belum mengikuti diskusi secara aktif masih ada 9 orang atau 25,00\%, dan jika dibandingkan dengan siklus pertama siswa yang belum mengikuti diskusi dengan aktif masih ada 14 orang atau $38,88 \%$ maka pada siklus kedua proses pembelajaran yang terkait dengan keaktifan berdiskusi ada peningkatan sebesar $13.88 \%$.

Perbandingan keaktifan siswa yang melakukan penyusunan kalimat pada siklus pertama dan siklus kedua dapat diketahui dari perbandingan hasil amatan berikut. Siswa yang sangat aktif menulis kalimat untuk mencari berbagai makna kata pada siklus pertama ada 9 orang atau sebayak 25\% dan siklus kedua 11 orang atau 30,55\% dan terjadi kenaikan 5,55\% sedangkan yang aktif menyusun kalimat untuk mencari makna kata pada siklus pertama sebanyak 11 orang atau 30,55\% dan jika dibandingkan dengan hasil pada siklus kedua ada 15 orang siswa atau sebanyak $41,66 \%$ menunjukkan ada peningkatan sebesar $15,89 \%$ sedangkan yang tidak sama sekali yang membuat kalimat pada siklus pertama ada 16 orang atau sebanyak $44,44 \%$, dan pada siklus kedua berkurang menjadi tinggal 10 orang atau sebesar $27,77 \%$ yang artinya terjadi peningkatan aktivitas siswa mengikuti pembelajaran pada aspek menulis kalimat untuk mencari makna kata sebesar $16,67 \%$.

Aspek yang diamati pada siklus kedua hampir seluruhnya mengalami peningkatan, meski belum maksimal, oleh sebab itu peneliti dan kolaborator melakukan diskusi tentang terkait masih adanya siswa yang belum aktif mengikuti proses pembelajaran. Oleh sebab itu peneliti dan kolaborator menyepakati pada siklus kedua perlu merangsang dan memotivasi siswa untuk terlibat secara aktif dalam pembelajaran. Upaya yang dilakukan adalah dengan memberikan pertanyaan yang terfokus pada siswa yang belum aktif, atau mengharuskan siswa bertanya pada siswa yang tidak aktif.

\section{KESIMPULAN}

Dari analisis data pada bab pembahasan dapat disimpulkan bahwa implementasi strategi Contektual Redefinition dapat meningkatkan penguasaan kosakata tetapi tidak dan dapat meningkatkan aktivitas pembelajaran. Rerata penguasaan kosakata siswa pada siklus pertama $28,00 \%$, dan rerata peningkatan penguasaan kosakata pada siklus kedua 32,77\% yang berarti terjadi kenaikan sebanyak $4,77 \%$, sedangkan rerata peningkatan skor penguasaan kosakata siswa pada siklus ketiga adalah $36,27 \%$ dan terdapat selisih kenaikan antara siklus kedua ke siklus ketiga sebesar 3,61\%. Peningkatan aktivitas pembelaja- 
ran siswa siklus pertama adalah 51,23\%, siklus kedua $61,09 \%$ dan siklus ketiga $65,79 \%$. Secara berurutan peningkatan aktivitas pembelajaran siklus pertama ke siklus kedua adalah 4,7\%, siklus kedua ke siklus ketiga juga sebesar 4,7\%.

\section{UCAPAN TERIMA KASIH}

Artikel ini di angkat dari laporan hasil penelitian yang dibiayai oleh dana Anggaran DIPA UNY tahun 2010 alokasi FBS. Ucapan terima kasih disampaikan kepada BPP penelitian FBS UNY yang telah mendanai dan menyelenggarakan seminar hasil penelitian. Selanjutnya, ucapan terima kasih disampaikan kepada guru dan siswa Kelas VIII E SMP Negeri I Seyegan, Sleman, Yogyakarta yang telah menjadi kolabrotor dan subjek dalam penelitian.

\section{DAFTAR PUSTAKA}

Adler, J. Mortimer \& Doren Van C. 2007. Cara Membaca Buku dan Memahaminya. PT. Pantja Simpati. Jakarta

Abdul, Chair. 2003. Psikolingusitik Kajian Teoritik. Renika Cipta. Jakarta

Barret. 2009. Barrett Taxonomy of Reading Comprehension. Artikel 2234 diambil dari www.slideshare.net/.../ chapter-2-

Burn, Paul C, Betty D.Roe, dan Elinor P. Ross. 1996. Teaching Reading in Today's Elementary School. Boston: Houghthon Mifflin Company

Brown, H. Douglas. 2000. Principles of Language Learning and Teaching Fourth Edition. New York: San Fransisco State University.

Brown, H. Douglas. 2001. Teaching by Principles: An Interactive Approach to Language Pedagogy. New York: San Fransisco State University

Brown, H. Douglas. 2004. Language Assessment Principles and Classroom Practices. New York: San Fransisco State University
Nurgiyantoro, Burhan,. 2001. Penilaian dalam Pengajaran Bahasa dan Sastra Indonesia. Yogykarta: Gadjah Mada University Prees

Collins. 2006. "Teaching Vocabulary". http:www.readingrockets./org./ articleorg diambil Mei 2009

Depdikanas. 2005. Kurikulum Tingkat Satuan Pendidikan. Jakarta: Depdiknas

Fisher dan Blachowicz. 1996. Teaching vocabulary in all classrooms. New Jersey: Englewood Cliffs

Harimurti K. 1999. Kamus Linguistik. Edisi ke tiga. Jakarta: PT Gramedia

Harris. AJ, \& E.R. Sipay. 1980. How to Inreace Reading Ability. New York: Longmen

Gutlohn \& Diamaon. 2006. "Vocabulary". www.brainyquote.com/ word/vo/vocabulary. Diambil Mei 2010

Keraf, Gorys. 2002. Diksi dan Gaya Bahasa. Jakarta. PT. Gramedia Pustaka Utama

Syamsi, Kastam. 2004. "Peningkatan Kemampuan Membaca Siswa SD dengan Pendekatan Proses". Yogyakarta: FBS UNY

Kemmis and Mc Taggart. 1990. Approach Focuses on Implementing and Produce the Classroom Action Research., www.cal.org/resources/digest/ digest_pdfs/0308donato/ Diambil Mei 2006.

Mufflin. 2006. "Vocabulary". .www.thefreedictionary.com. vocabulary. Diambil Mei 2010

Prayudi, Yudi Yusuf. 2007. Proses Pembelajaran diambil .http://Word Press. Com Artikel 0012. Diakses 15 Mei 2010

Hernacki M, Deporster Bobbi. 1992. Quantum Learning: Membiasakan Belajar Nyaman dan Menyenangkan. Bandung: Kaifa 
Hedge Grasicia. 2008. Teaching and Learning in the Language Classroom. Oxford University Press. New York. USA.

Jocobsen A David, \&Eggen Paul, \& Kaucchak D. (2004) Methods for Teaching Promoting Student Learning in k-12 Classrooms. New Jersey: Pearson Merrill Prentice Hall

Iskandarwassid \& Dadang Suhendar. 2008. Strategi pembelajaran bahasa. Bandung: PT Remaja Rosdakarya.

Johnson, B. Elaine. 2002. Contekxtual Teaching and Learning: Menjadikan Kegiatan Belajar Mengajar Mengasyikkan dan Bermakna. Terjemahan Ibnu Setiwan. Bandung: Mizan Media Utama

Law,S. \& Glover D. 2005. Improving Learning.Professinal Practice in Secondary Schools. Jakarta: Grasindo

Marliana, Lia, N.\& Suriana Asep. 2005. "Contextual Teaching And Learning (CTL) Pada Pembelajaran Mata Kuliah Pengembangan Kepribadian Bahasa Indonesia di Universitas Negeri Jakarta: Jurnal Humaniora. Volume 3 No 2. Jurusan MKU Univeritas Negeri Jakarta.

Miller Debbie. 2002. Reading Whit Meaning Theaching Comprehension in the Primary Grades. Markham, Ontario L3R 3K9 : Canada.

Pringgowardagda, Suwarna. 2002. Strategi Penguasaan Berbahasa. Yogyakarta: Adicita Karya Nusa

Rohani, A. 2004. Pengelolaan pengajaran. Jakarta: Rineka Cipta
Suhardi \& Zamzani. 2005. "Strategi penggunaan skemata mahasiswa dalam pembelajaran membaca: upaya meningkatkan efektivitas membaca". Jurnal Litera Volume 4, No 2 FBS UNY

Suwarsih Madya. 1999. Penelitian Tindakan Kelas. Yogyakarta: Lemlit UNY

Syafi'ie, Imam. et al. 2001. Pendekatan Pembelajaran Bahasa Indonesia. Jakarta: Pusat Penerbitan Univeritas Terbuka

Syafi'ie, Imam. 1996. Membaca sebagai Sutu Keterampilan Berbahasa. Bandung: Angkasa

Zucdhi, Darmiyati. 2004. Peningkatan Kemampuan Memahami Bacaan dan Kemandirian dengan Teknik Rencana Prabaca. Jurnal Litera Volume 3 No. 2 Juli. FBS UNY

Zucdhi, Darmiyati. dkk. 1997. "Kosakata Baca Bahasa Indonesia untuk Sekolah Dasar di Indonesia". Yogyakarta: Laporan Penelitian OPF IKIP.

Zucdhi, Darmiyati. 1995. "Strategi Meningkatkan Kemampuan Membaca: Peningkatan Pemahaman Bacaan". Yogyakarta: FPBS IKIP Yogyakarta.

Wainwright, Gordon. 2002. Speed Reading Better Recalling: Manfaatkan Teknik Teruji untuk Membaca Lebih Cepat dan Mengingat Secara Maksimal. Jakarta: Gramedia Pustaka Utama.

Wall Amy \& Wall Regina. 2005. The Complete Idiot's Guide to Critical Reading. Ney York: Alpa Books Penguin Group 